\title{
Copper deficiency in chicks: effects of ascorbic acid on iron, copper, cytochrome oxidase activity, and aortic mucopolysaccharides
}

\author{
By C. E. HUNT,* JOANNE LANDESMAN AND P. M. NEWBERNE \\ Department of Nutrition and Food Science, Massachusetts Institute of Technology, \\ Cambridge, Massachusetts $02139, U S A$
}

(Received 4 August 1969-Accepted 20 Fanuary 1970)

\begin{abstract}
I. Copper deficiency was induced in newly hatched chicks by feeding on a milk-based diet for $12 \mathrm{~d}$; effects of supplementation with ascorbic acid were studied.

2. $\mathrm{Cu}$ deficiency alone resulted in $30 \%$ mortality from aortic rupture. This was associated with a $20 \%$ increase in total acid mucopolysaccharides in the aorta, manifested as an increase in chondroitin sulphate and a relative decrease in hyaluronic acid. Cytochrome oxidase activity of liver and heart was less than half that of the controls.

3. Supplementing the Cu-deficient diet with $0.5 \% \mathrm{~L}$-ascorbic acid increased mortality to $40 \%$, raised total aortic acid mucopolysaccharides to a higher level, and increased liver iron by $36 \%$.

4. Supplementing the control diet with ascorbic acid decreased liver $\mathrm{Cu}$ by $30 \%$ and significantly reduced total aortic acid mucopolysaccharides.

5. The enhancement of the Cu-deficiency effect by ascorbic acid probably results from interactions between ascorbic acid and absorption or metabolism of $\mathrm{Cu}$; untoward effects of supplementing the control diet with ascorbic acid may be interpreted as manifestations of ascorbic acid toxicity per se.
\end{abstract}

Chicks have been used extensively as an experimental model for copper-deficiency studies, principally because eggs contain little $\mathrm{Cu}$ and day-old chicks reared on a $\mathrm{Cu}$-deficient diet rapidly develop the signs and lesions of deficiency. Elvehjem \& Hart (1929) first studied the effect of $\mathrm{Cu}$ on anaemia in the chick. More recently, other workers have investigated the $\mathrm{Cu}$ requirement of this species and confirmed its need in haematopoiesis (Carlton \& Henderson, I964 $b$; Hill \& Matrone, 1961). O'Dell, Hardwick, Reynolds \& Savage ( $196 \mathrm{I}$ ) reported that $\mathrm{Cu}$ is essential for the development and maintenance of the cardiovascular system of chicks. Shortly thereafter, Carlton $\&$ Henderson (1963) published a histopathological evaluation describing a defect in elastin in the major vessels of $\mathrm{Cu}$-deficient chicks. Subsequently, results of several studies have implicated $\mathrm{Cu}$ in the formation of the elastin cross-links, desmosine and isodesmosine (Hill, Starcher \& Kim, I967; Partridge, I966). Other components of connective tissue are also altered in aortas from $\mathrm{Cu}$-deficient animals (Linker, Coulson \& Carnes, I 964; O’Dell, Bird \& Ruggles, r966; Weissman, Shields \& Carnes, 1963). In addition to the above changes, bone lesions (Carlton \& Henderson, I964a) and reduced cytochrome oxidase activity in heart (Hill \& Matrone, I96I) have been observed in $\mathrm{Cu}$-deficient chicks.

The severity of $\mathrm{Cu}$ deficiency in chicks is increased when the diet is supplemented

* Present address: Department of Comparative Medicine, University of Alabama, Birmingham, Alabama, USA. 
with ascorbic acid (Carlton \& Henderson, 1965; Hill \& Starcher, 1965). We have investigated this apparent interrelationship and report here the effects of $\mathrm{Cu}$ and ascorbic acid on tissue iron and $\mathrm{Cu}$, cytochrome oxidase activity, and aortic mucopolysaccharides (MPS) in the chick.

\section{EXPERIMENTAL}

For these studies we used pigmented, sex-linked cockerels (Barred Plymouth Rock) purchased from a commercial hatchery (Hall Brothers Hatchery, Wallingford, Conn.). Groups of birds were received at $14 \mathrm{~d}$ intervals; within $12-24 \mathrm{~h}$ after hatching they had been weighed and distributed at random into experimental groups in electrically

\section{Table I. Composition of the copper-deficient diet}

\begin{tabular}{lr} 
Component & $\begin{array}{c}\text { Amount } \\
(\mathrm{g} / \mathrm{kg})\end{array}$ \\
Dried skim milk & 600 \\
Glycine & 4 \\
DL-Methionine & 3 \\
L-Arginine & 4 \\
Sucrose & $\mathrm{I} 33$ \\
Starch & $\mathrm{I33}$ \\
Maize oil* & 50 \\
Mineral mix $\dagger$ & 50 \\
Vitamin mix $f$ & 20 \\
Choline chloride & 3 \\
\multicolumn{1}{c}{ Total } & $\mathrm{I} 000 \mathrm{~g}$
\end{tabular}

* Mazola oil; Best Foods Division, Corn Products Co., New York, NY.

$\uparrow$ Special Cu-deficient salt mix purchased from General Biochemicals, Inc., Chagrin Falls, Ohio. The mix provided the following elements (mg/kg diet): Mg, 300; Fe, 20; Mn, 100; Zn, $15 ; \mathrm{I}, 0.19$.

† The mix provided the following vitamins $(\mathrm{mg} / \mathrm{kg} \mathrm{diet})$ : thiamine hydrochloride, 20; riboflavine, 20; pyridoxine hydrochloride, 20; calcium pantothenate, 40; nicotinic acid, 30; inositol, 50; folic acid, 2; biotin, 0.15 ; menaphthone, 4 ; DL- $\alpha$-tocopherol acetate, 50; vitamin A acetate and ergocalciferol, $975^{\circ}$ and 975 USP units respectively. The following were added separately (per kg diet): cyanocobalamin in aqueous solution, $20 \mu \mathrm{g}$, and crystalline cholecalciferol in oil, 250 USP units.

heated battery brooders. Feed and distilled water were supplied ad lib. in stainless steel containers. The diet was based on dried skim milk supplemented with all vitamins, minerals, and amino acids necessary for chick growth (Table I). The basal diet consistently contained less than I $\mu \mathrm{g} \mathrm{Cu} / \mathrm{g}$. $\mathrm{Cu}$, as reagent-grade cuprous chloride $(\mathrm{CuCl})$, was added in a starch premix to the basal diet to provide a control diet that contained $6 \mu \mathrm{g} \mathrm{Cu} / \mathrm{g}$. Four experimental groups were studied: control, $\mathrm{Cu}$-deficient, control plus $0.5 \%$ L-ascorbic acid, and Cu-deficient plus $0.5 \% \mathrm{~L}$-ascorbic acid. There were four identical experiments; each included twenty-five birds per group.

The chicks were killed by decapitation after $12 \mathrm{~d}$ on the experiment. Chicks that were crippled or otherwise incapacitated were rejected for analyses. Whole blood was collected in polyethylene containers for haemoglobin and haematocrit determinations. Haemoglobin was measured as oxyhaemoglobin, and the packed cell volume was measured with heparinized micro-haematocrit capillary tubes. Samples of blood and liver were frozen for mineral analyses at a later date; at the time of analysis 
they were digested in a mixture of concentrated nitric acid and $70 \%$ perchloric acid $(\mathrm{x}: \mathrm{I}, \mathrm{v} / \mathrm{v})$. All glassware was washed, rinsed once in $10 \%$ aqueous hydrochloric acid, then rinsed three times in deionized distilled water. The digested samples of blood and liver were analysed for $\mathrm{Fe}$ and $\mathrm{Cu}$ by atomic absorption spectrophotometry using individual cathode lamps (Perkin-Elmer Model 303; Perkin-Elmer Corp., Norwalk, Conn.).

Portions of the thoracic aorta, heart, liver, spleen, duodenum, and pancreas were fixed in freshly prepared, cold, buffered $10 \%$ formalin. Tissues were trimmed, paraffin-embedded, and cut at $6 \mu \mathrm{m}$ for staining with haematoxylin and eosin. Selected sections of arteries were stained for elastic tissue by the method of Verhoeff \& Hale (Armed Forces Institute of Pathology, 1960) and for acid MPS by colloidal iron. Liver, spleen, duodenum, and pancreas were stained for Fe by the Gomori technique (Armed Forces Institute of Pathology, 1960).

Cytochrome oxidase (ferrocytochrome $c$ : oxygen oxidoreductase, $E C \quad$ 1.9.3.1) activity was measured spectrophotometrically on $5 \%$ homogenates of liver and heart. The substrate, cytochrome $c$ (Sigma Chemical Co., St Louis, Mo.), was prepared as described by Neufeld, Levay, Lucas, Martin \& Stotz (1960). Liver and heart were chilled immediately in phosphate buffer $\left(\mathrm{pH}_{7} \cdot 4\right)$, weighed, minced with stainless steel scissors, and homogenized in an Omni-Mixer (Ivan Sorvall, Inc., Norwalk, Conn.). The rate of oxidation of reduced cytochrome $c$ was determined by measuring the decrease in optical density at $55^{\circ} \mathrm{nm}$. Protein was estimated according to the method of Lowry, Rosebrough, Farr \& Randall (1951).

Aortas with attached carotid arteries were preserved in acetone (AR) after removal of the adventitia. Extraction and identification of acid MPS were performed according to methods described by Gore, Tanaka, Fujinami \& Goodman (1965).

Standard error of the mean was calculated and Student's $t$ test used to determine significance of values. These values are recorded in the results section.

\section{RESULTS}

Visible evidence of $\mathrm{Cu}$ deficiency was apparent in about $7 \mathrm{~d}$. The most prominent signs were lameness and respiratory distress. Those animals with respiratory distress often exhibited internal haemorrhage and haemopericardium at post-mortem examination. Weight gains were poorest in birds given the $\mathrm{Cu}$-deficient diet supplemented with $0.5 \% \mathrm{~L}$-ascorbic acid. The mortality rate in this group usually approached $40 \%$ by $12 \mathrm{~d}$; mortality in the $\mathrm{Cu}$-deficient chicks did not exceed $30 \%$ during the same period. In both groups death was generally associated with massive haemorrhage into the thorax or peritoneal cavity. The $\mathrm{Cu}$ content of the diet was a critical factor with respect to mortality and varied from 0.56 to $0.87 \mu \mathrm{g} / \mathrm{g}$ in these experiments. To test the effects of ascorbic acid in a practical diet, we included the vitamin at a level of $5.0 \%$ for a $42 \mathrm{~d}$ period. Compared with the controls, growth, haemoglobin, and haematocrit were not affected.

Livers and blood from five chicks were pooled, and twelve such composite samples from each treatment group were analysed for $\mathrm{Fe}$ and $\mathrm{Cu}$. These results are summarized 
in Fig. I. Ascorbic acid had a greater effect than $\mathrm{Cu}$ on the concentration of $\mathrm{Fe}$ in the tissues. In fact, $\mathrm{Cu}$ deficiency altered the concentration of $\mathrm{Fe}$ in the liver only when the diet was supplemented with the vitamin. In birds fed on the $\mathrm{Cu}$-deficient diet plus ascorbic acid the concentration of liver $\mathrm{Fe}$ was $36 \%$ greater than in birds fed on the control diet supplemented with ascorbic acid $(45 \cdot 3 \pm 2 \cdot 6$ compared with $33 \cdot 3 \pm 1 \cdot 6$, $P<0.005)$. Supplementary ascorbic acid also was associated with an increase in blood Fe (Fig. I).

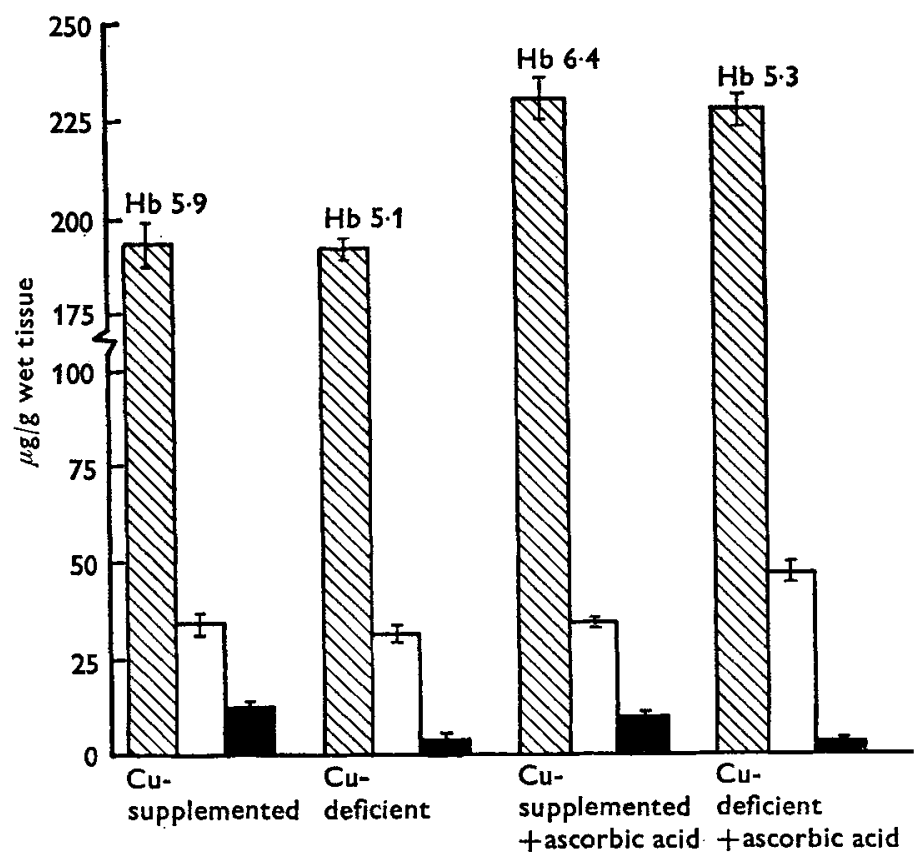

Fig. I. Copper and iron values in whole blood and livers of chicks (mean values with their standard errors for twelve samples, each from five chicks). Values for haemoglobin $\mathrm{Fe}(\mathrm{g} / \mathrm{I} 00 \mathrm{~g}$ whole blood; mean values for ten chicks), determined as oxyhaemoglobin, are shown above the

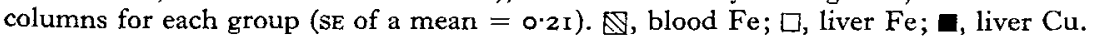

The $\mathrm{Cu}$ content of the liver was affected mainly by dietary $\mathrm{Cu}$ and its concentration was three times greater in the livers of birds from the $\mathrm{Cu}$-supplemented than in those from the corresponding $\mathrm{Cu}$-deficient group (Fig. $\mathrm{I}$ ). Addition of ascorbic acid to the $\mathrm{Cu}$-supplemented diet decreased liver $\mathrm{Cu}$ by $30 \%(\mathrm{x} 2 \cdot 4 \pm \mathrm{I} \cdot 6$ compared with $8 \cdot 8 \pm \mathrm{I} \cdot 8$, $P<0.005)$. Blood $\mathrm{Cu}$ varied slightly among treatment groups and, in all instances, was less than $45 \mu \mathrm{g} / 100 \mathrm{ml}$ whole blood.

Total acid MPS were determined in the thoracic aorta together with the first $1 \cdot 3 \mathrm{~cm}$ of the carotid arteries. As shown in Table 2, a $20 \%$ increase in aortic acid MPS was associated with $\mathrm{Cu}$ deficiency. The increase was considerably greater $(46 \%)$ when ascorbic acid was given. Addition of ascorbic acid to the control diet resulted in a decrease in acid MPS. Upon separation and identification of the acid MPS, we found that the percentage of hyaluronic acid was decreased in aortas of $\mathrm{Cu}$-deficient birds, with a resulting increase in the chondroitin sulphate group (Table 2). The effect was 
reversed in aortas from birds given ascorbic acid together with the control diet, i.e. chondroitin sulphate was decreased.

Cytochrome oxidase activity was reduced significantly in homogenates of liver and heart from $\mathrm{Cu}$-deficient chicks (Table 3 ). Results were similar in both liver and heart from birds given the diets supplemented with ascorbic acid. Differences in cytochrome oxidase activity which could be attributed only to ascorbic acid were not significant for the number of birds in this study.

'Table 2. Acid mucopolysaccharides in chick aorta (mean values with their standard errors for twelve samples, each of five aortas)

$\begin{array}{cccc}\text { Total } & \text { Hyaluronic } & \text { Chondroitin } \\ \text { Diet } & \text { acid } & \text { sulphate group } \\ (\mathrm{mg} / \mathrm{g}) & (\%) & (\%)\end{array}$

Control

Copper-deficient

Control + ascorbic acid

Copper-deficient + ascorbic acid

$$
\begin{array}{r}
10.95 \pm 0.23 \\
13.30 \pm 0.37^{*} \\
9.68 \pm 0.26 \dagger \\
14.23 \pm 0.33 \ddagger
\end{array}
$$

I I. $9 \pm 0 \cdot 5$

$6 \cdot 6 \pm 0 \cdot 4$

$\mathrm{r} 3 \cdot 2 \pm 0 \cdot 8$

$88 \cdot 1 \pm 0 \cdot 5$

$90 \cdot 1 \pm 0.4$

$86 \cdot 8 \pm 0.8$

$88 \cdot 7 \pm 0 \cdot 7$

* Significantly greater than control $(P<$ o.oor $)$.

+ Significantly less than control $(P<0.005)$.

$\ddagger$ Significantly greater than control + ascorbic acid $(P<0.001)$.

Table 3. Cytochrome oxidase activity* of chick tissues (mean values with their

\begin{tabular}{|c|c|}
\hline \multicolumn{2}{|c|}{ Heart } \\
\hline $\begin{array}{c}\text { Activity/ } \\
\text { mg dry weight }\end{array}$ & $\begin{array}{c}\text { Activity/ } \\
\text { mg protein }\end{array}$ \\
\hline $8.2 \pm 0.2$ & $23.3 \pm 0.7$ \\
\hline $3.5 \pm 0.7$ & $8 \cdot 0 \pm 1 \cdot 7$ \\
\hline $8 \cdot 2 \pm 1 \cdot 4$ & $247 \pm 4.0$ \\
\hline $3.4 \pm 0.5$ & $7 \cdot 7 \pm x \cdot 1$ \\
\hline
\end{tabular}
standard errors for three samples, each from two birds)

$\overbrace{\begin{array}{c}\text { Ascorbic acid } \\ \text { added }\end{array}}^{\text {Diet }} \begin{array}{ll}\begin{array}{c}\text { Copper } \\ \text { status }\end{array} \\ \text { None } & \begin{array}{l}\text { Supplemented } \\ \text { None }\end{array} \\ 0.5 \% & \text { Supplent } \\ 0.5 \% & \text { Deficient }\end{array}$

$\begin{array}{cr}\begin{array}{c}\text { Activity/ } \\ \text { mg dry weight }\end{array} & \begin{array}{c}\text { Activity/ } \\ \text { mg proteint }\end{array} \\ 6.3 \pm 0.4 & \text { II.6 } \pm 0.4 \\ 2.2 \pm 0.6 & 3.4 \pm 1 \cdot 1 \\ 5.5 \pm 0.3 & 11.0 \pm 0.7 \\ 2.6 \pm 0.2 & 4.5 \pm 0.3\end{array}$

* Change in optical density $\times 10^{2}$.

+ Livers from $\mathrm{Cu}$-deficient chicks significantly less active than those from $\mathrm{Cu}$-supplemented chicks $(P<0.025)$.

I Hearts from $\mathrm{Cu}$-deficient chicks significantly less active than those from $\mathrm{Cu}$-supplemented chicks $(P<0.01)$.

\section{DISCUSSION}

The level of $\mathrm{Fe}$ in the liver and blood of chicks did not appear to be affected by $\mathrm{Cu}$ intake alone. This finding contrasts with studies on rats (Chase, Gubler, Cartwright $\&$ Wintrobe, 1962) and pigs (Gubler, Cartwright \& Wintrobe, 1957) in which there was a marked reduction in liver and total body Fe of $\mathrm{Cu}$-deficient animals. Nacht, Lee, Cartwright \& Wintrobe (1967) observed increased amounts of Fe in the duodenal epithelium of $\mathrm{Cu}$-deficient pigs and concluded that, while uptake of $\mathrm{Fe}$ by duodenal mucosa was normal, transfer of $\mathrm{Fe}$ to the blood was blocked. In our studies Fe did not accumulate in the duodenal mucosa of Cu-deficient chicks (as judged by Prussianblue staining). The difference between our results and those of Nacht et al. (1967) may be partly attributable to species variation. However, it is probably best explained by length of study and $\mathrm{Fe}$ content of the diet: our experiments were of short duration 
(12 d) and the diet was marginal in $\mathrm{Fe}$ (Hill \& Matrone, 196r). Using the level of haemoglobin as an index, Hill \& Matrone found a reciprocal relationship between dietary $\mathrm{Fe}$ and $\mathrm{Cu}$ in the chick, i.e. as $\mathrm{Fe}$ was increased, less $\mathrm{Cu}$ was needed and vice versa. Perhaps the inclusion of higher levels of $\mathrm{Fe}$ in our diets for a longer period of time would reveal a relationship between $\mathrm{Fe}$ absorption and $\mathrm{Cu}$ intake in the chick. Such a study would require determination of mucosal and total body $\mathrm{Fe}$.

It is well established that ascorbic acid promotes $\mathrm{Fe}$ absorption in the intestine; this is probably the result of its reducing action and chelation (Hopping \& Ruliffson, 1966). In our studies, blood and liver Fe were increased in birds given ascorbic acid in a Cu-deficient diet. In other groups of chicks almost all of the blood Fe can be accounted for as haemoglobin on the basis of $3.35 \mathrm{mg} \mathrm{Fe} / \mathrm{g}$ haemoglobin. Haemolysis would be expected to increase liver $\mathrm{Fe}$, and in $\mathrm{Cu}$-deficient pigs the life span of red cells is decreased (Bush, Jensen, Athens, Ashenbrucker, Cartwright \& Wintrobe, 1956). We stained sections of liver and spleen for $\mathrm{Fe}$ but found no increase in the $\mathrm{Fe}$ content of the reticuloendothelial cells. Consequently, we assume that the increased concentration was present in hepatic cells. Furthermore, the anaemia associated with $\mathrm{Cu}$ deficiency in chicks is the result of a decreased production of red cells rather than of haemolysis (Carlton \& Henderson, 1964 $b$; Hill \& Matrone, 1961). Under the conditions of our experiments, ascorbic acid may have promoted $\mathrm{Fe}$ absorption. Perhaps, in the $\mathrm{Cu}$-deficient chicks that were given the vitamin, low levels of $\mathrm{Cu}$ in the liver prevented movement of $\mathrm{Fe}$ from this organ.

Liver $\mathrm{Cu}$ was reduced significantly in chicks given ascorbic acid. This may have resulted from decreased absorption of $\mathrm{Cu}$ in the presence of the vitamin. The results of Hill \& Starcher (1965) indicate that the role of reducing agents, including ascorbic acid, in increasing the severity of Cu deficiency is related to the intermediate metabolism of $\mathrm{Cu}$ rather than to an inhibitory effect on absorption. These investigators noted that there was no significant reduction in concentration of liver $\mathrm{Cu}$ as a result of a diet containing $0.1 \%$ ascorbic acid. However, after dosing with radioactive $\mathrm{Cu}$, they found less radioactivity in livers of chicks given additional ascorbic acid than in livers from those given the control diet. The question is still unsettled, but we feel that ascorbic acid may affect either absorption or utilization of $\mathrm{Cu}$.

The absolute increase in acid MPS in aortas from Cu-deficient chicks observed in our studies is in accord with results reported by other investigators, in which the hexosamine content was increased in aortas from Cu-deficient chicks (O'Dell et al. 1966) and pigs (Weissman et al. 1963). Furthermore, the ratio of hyaluronic acid to chondroitin sulphate was altered, with a resulting proportional increase in the latter. Although we did not identify and measure the individual chondroitin sulphates this observation seems to parallel that reported by Linker et al. (1964) that chondroitin sulphate $\mathrm{B}$ was increased in aortas from $\mathrm{Cu}$-deficient pigs. The primary defect which leads to formation of dissecting aneurysms and rupture of major vessels in $\mathrm{Cu}$ deficient chicks and pigs has been defined biochemically as a failure in elastin synthesis (Hill et al. 1967; Partridge, 1966). Therefore our results agree with the conclusion of Coulson \& Linker (1968) that the increase in aortic acid MPS is a secondary manifestation of Cu deficiency. 
The effects of ascorbic acid on MPS in chick aortas are sufficiently interesting to warrant further investigation. When the vitamin was added to the $\mathrm{Cu}$-deficient diet, the changes in MPS associated with uncomplicated Cu deficiency were exacerbated. If our interpretation is correct, this may be an attempt to compensate for the greater reduction in aortic elastin under these conditions (Hill \& Starcher, 1965). We did not expect to observe exactly the opposite effect in aortas from birds given ascorbate in the control diet, i.e. total MPS were decreased and the chondroitin sulphates were reduced relative to hyaluronic acid. These findings may correlate with those of Kofoed \& Robertson (1966) in guinea-pig cartilage. Their results suggest that ascorbic acid may inhibit synthesis of chondroitin sulphate. Chicks given our experimental diet supplemented with ascorbic acid and adequate $\mathrm{Cu}$ always grew at least as well as the controls; therefore, our results were not due to inanition.

Cytochrome oxidase activity is reduced in tissues of various mammalian species made deficient in $\mathrm{Cu}$, and we wanted to determine the effect of ascorbic acid on the activity of this enzyme under our experimental conditions. $\mathrm{Cu}$ deficiency caused a significant reduction in cytochrome oxidase activity in liver and heart, but this effect was not accentuated by dietary ascorbic acid. The results contrast with those obtained in rabbits given a $\mathrm{Cu}$-deficient diet supplemented with the vitamin (Hunt, Carlton \& Newberne, 1970). Cytochrome oxidase activity was reduced to a greater degree in hearts from these animals than in hearts from those which were simply Cu-deficient. Activity in liver was the same in both groups. $\mathrm{Cu}$ and haemin $a$ (I:I ratio) are the functional prosthetic groups of cytochrome oxidase (Griffiths \& Wharton, I96r; Morrison, Horie \& Mason, ${ }^{1963}$ ) and the effect of $\mathrm{Cu}$ deficiency on the activity of this enzyme may be related to the absence of one or both of these constituents. The haemin $a$ content is reduced greatly in hearts from Cu-deficient rats (Gallagher, Judah \& Rees, 1956) and pigs (Lemberg, Newton \& Clarke, 1962). Consequently, the observed loss of activity of cytochrome oxidase may be ascribed to an inhibition of enzyme synthesis as a result of insufficient haemin $a$.

Our results provide additional evidence that the severity of $\mathrm{Cu}$ deficiency is increased by including ascorbic acid in a purified diet. Further studies are needed to elucidate the reasons for the effects we observed and to determine in what way(s) ascorbic acid influences $\mathrm{Cu}$ absorption or metabolism, or both, in chicks.

This investigation was supported by grants HE-IOII2 and GM-II33 from the National Institutes of Health and by a grant from Smith, Kline and French Pharmaceutical Co., Philadelphia, Pa. The manuscript is contribution no. 1414 from the Department of Nutrition and Food Science, Massachusetts Institute of Technology.

\section{REFEREN CES}

Armed Forces Institute of Pathology (1960). Manual of Histologic and Special Staining Technics 2 nd ed. New York: McGraw-Hill Book Company.

Bush, J. A., Jensen, W. N., Athens, J. W., Ashenbrucker, M., Cartwright, G. E. \& Wintrobe, M. M. (1956). F. exp. Med. ro3, 7or.

Carlton, W. W. \& Henderson, W. (1963). f. Nutr. 81, 200.

Carlton, W. W. \& Henderson, W. (I964a). Avian Dis. 8, 48. 
Carlton, W. W. \& Henderson, W. (1964b). Avian Dis. 8, 227.

Carlton, W. W. \& Henderson, W. (1965). F. Nutr. 85, 67.

Chase, M. A., Gubler, C. J., Cartwright, G. E. \& Wintrobe, M. M. (1962). F. biol. Chem. 199, 757.

Coulson, W. F. \& Linker, A. (1968). Biochim. biophys. Acta 158, r 17.

Elvehjem, C. A. \& Hart, E. B. (1929). J. biol. Chem. 84, I31.

Gallagher, C. H., Judah, J. D. \& Rees, K. R. (1956). Proc. R. Soc. B I45, I34.

Gore, I., Tanaka, Y., Fujinami, T. \& Goodman, M. L. (1965). F. Nutr. 87, 3 I I.

Griffiths, D. E. \& Wharton, D. C. (1961). Y. biol. Chem. 236, 1850.

Gubler, C. J., Cartwright, G. E. \& Wintrobe, M. M. (1957). F. biol. Chem. 224, 533.

Hill, C. H. \& Matrone, G. (I961). F. Nutr. 73, 425.

Hill, C. H. \& Starcher, B. (1965). F. Nutr. 85, 27 I.

Hill, C. H., Starcher, B. \& Kim, C. (1967). Fedn Proc. Fedn Am. Socs exp. Biol. 26, 129.

Hopping, J. M. \& Ruliffson, W. S. (1966). Am. Y. Physiol. 210, 1316.

Hunt, C. E., Carlton, W. W. \& Newberne, P. M. (1970). Br. F. Nutr. 24, 6r.

Kofoed, J. A. \& Robertson, W. Van B. (1966). Biochim. biophys. Acta 124, 86.

Lemberg, R., Newton, N. \& Clarke, L. (1962). Aust. F. exp. Biol. med. Sci. 40, 367.

Linker, A., Coulson, W. F. \& Carnes, W. H. (1964). F. biol. Chem. 239, I69o.

Lowry, O. H., Rosebrough, N. J., Farr, A. L. \& Randall, R. J. (1951). F. biol. Chem. 193, 265.

Morrison, M., Horie, S. \& Mason, H. S. (1963). F. biol. Chem. 238, 2220.

Nacht, S., Lee, G. R., Cartwright, G. E. \& Wintrobe, M. M. (r967). Fedn Proc. Fedn Am. Socs exp. Biol. 26, 634.

Neufeld, H. A., Levay, A. N., Lucas, F. V., Martin, A. P. \& Stotz, E. (1960). J. biol. Chem. $233,209$. O’Dell, B. L., Bird, W. \& Ruggles, D. L. (I966). J. Nutr. 88, 9.

O'Dell, B. L., Hardwick, B. C., Reynolds, G. \& Savage, J. E. (I961). Proc. Soc. exp. Biol. Med. 1o8, 402. Partridge, S. M. (1966). Fedn Proc. Fedn Am. Socs exp. Biol. 25, 1023.

Weissman, N., Shields, G. S. \& Carnes, W. H. (1963). F. biol. Chem. 238, 3115. 